\title{
Elongation pattern of styloid process in Saudi population: a factor to remember in the prevention of Eagle syndrome
}

\author{
A. Alsweed ${ }^{1}$ (1) B.M. Almutairi2(1) \\ 'Saudi Board of Paediatric Dentistry, Saudi Commission for Health Specialties, Riyadh, Kingdom of Saudi Arabia \\ 2Department of Oral and Maxillofacial Surgery and Diagnostic Sciences, College of Dentistry in Ar Rass, Qassim \\ University, Saudi Arabia
}

[Received: 3 June 2021; Accepted: 27 July 2021; Early publication date: 3 August 2021]

\begin{abstract}
Background: The aim of this study is to determine the prevalence of styloid process (SP) patterns in Saudi population.

Materials and methods: This retrospective, cross-sectional study included 2010 digital panoramic radiographs (PRs) selected randomly for adult patients who visited five major hospitals in the Qassim region, Saudi Arabia, PRs were examined to detect any SP elongation. Data were collected and analysed using SPSS V22. Results: In this study, positive SP elongation was seen in $25.4 \%$ of the total cases, $14.2 \%$ and $11.2 \%$ male and female, respectively. The mean age was $34.3 \pm$ \pm 13.9 years. Type / was found in $19.1 \%$, type II in $1.7 \%$, and type III in $4.6 \%$ of the cases. Normal SP was seen in $74.7 \%$. Patients between 30 and 50 years were significantly more affected with type I pattern. Normal SP was reported mostly in the youngest age group 18-24 years, in 31\% of total cases.

Conclusions: Styloid process has many patterns and variations that could be detected on digital PRs taken daily in most of dental clinics. Dentists should be trained to detect patients with such variation so that signs associated with Eagle syndrome are not misinterpreted. (Folia Morphol 2022; 81, 3: 701-706)
\end{abstract}

Key words: elongated styloid process, eagle syndrome, panoramic radiograph

\section{INTRODUCTION}

$\mathrm{X}$-ray considers the window that views all activities of the human body, either normal anatomy of the body or abnormal, physiological or pathological activities. One of the of X-ray divisions is orthopantomogram or panorama radiography which is a radiologic technique that provides an overview of the jaws and surrounding structures [23]. Panoramic radiographs (PRs) enable the dentist to see a wide area of the maxilla and mandible $[24,25]$. It is considered one of the best imaging modalities to view the styloid process (SP) bilaterally [26]. The SP is a cylindrical bone that emerges from the temporal bone in front of the stylomastoid foramen. It is usually around $25 \mathrm{~mm}$ in length, but it can vary from person to person, and even within the same person, from side to side [27]. Elongated SP has been examined in several populations by distinctive methods and techniques, either advanced or traditional. Wide variation prevalence of SP elongation was noted,

Address for correspondence: Dr. A. Alsweed, Saudi Board of Paediatric Dentistry, Saudi Commission for Health Specialties, Riyadh, Kingdom of Saudi Arabia, e-mail: A.alswed@gmail.com

This article is available in open access under Creative Common Attribution-Non-Commercial-No Derivatives 4.0 International (CC BY-NC-ND 4.0) license, allowing to download articles and share them with others as long as they credit the authors and the publisher, but without permission to change them in any way or use them commercially. 


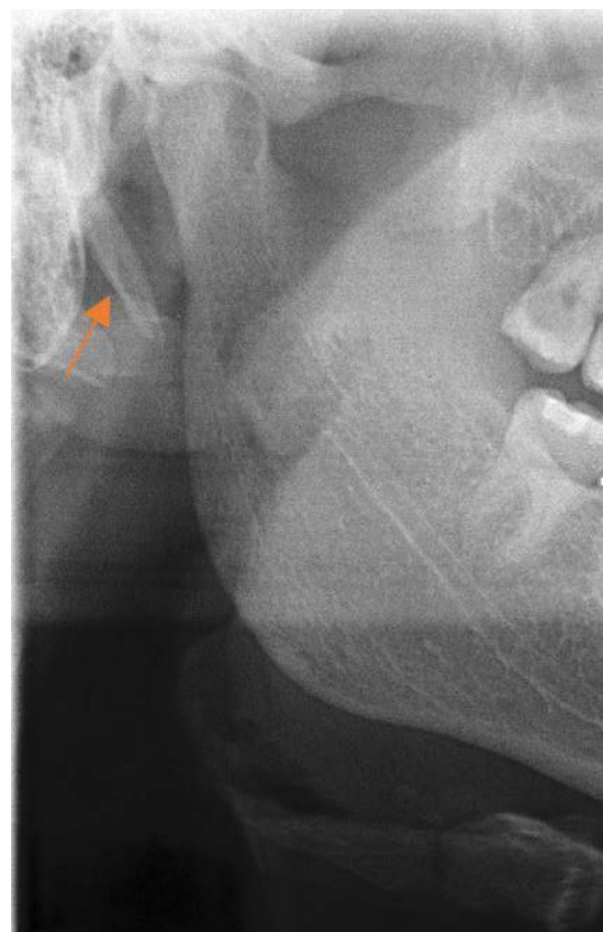

Figure 1. Radiograph show type 0 elongated styloid process.

extending from $4 \%$ to $30 \%$ [33]. Elongated SP comes usually with no symptoms. Eagle et al. [8] reported only $4 \%$ to $10.3 \%$ symptomatic cases characterising Eagle syndrome also known as styloid syndrome. Eagle syndrome symptoms may include throat pain or foreign body sensation, dysphagia, or facial pain. It may also cause neck or throat pain that radiate to the ipsilateral ear [9]. The cause is unknown, but several hypotheses have been proposed, including congenital elongation due to the persistence of an embryonic cartilaginous outgrowth, calcification of the stylohyoid ligament, and development of bone tissue at the ligament's insertion [10, 28]. SP can be assessed using an anatomical structure. An elongated SP and calcification of the stylohyoid ligament can be detected with proper clinical and radiographic examination [25]. This aim of this study is to determine the prevalence of SP patterns in Saudi population.

\section{MATERIALS AND METHODS}

This retrospective, cross-sectional study included 2010 digital PRs selected randomly for adult patients who visited five major hospitals in the Qassim region (Qassim University Dental Hospital, King Fahd Specialist Hospital, Buraydah Central Hospital, King Saud Hospital, and Alrass General Hospital) for den-

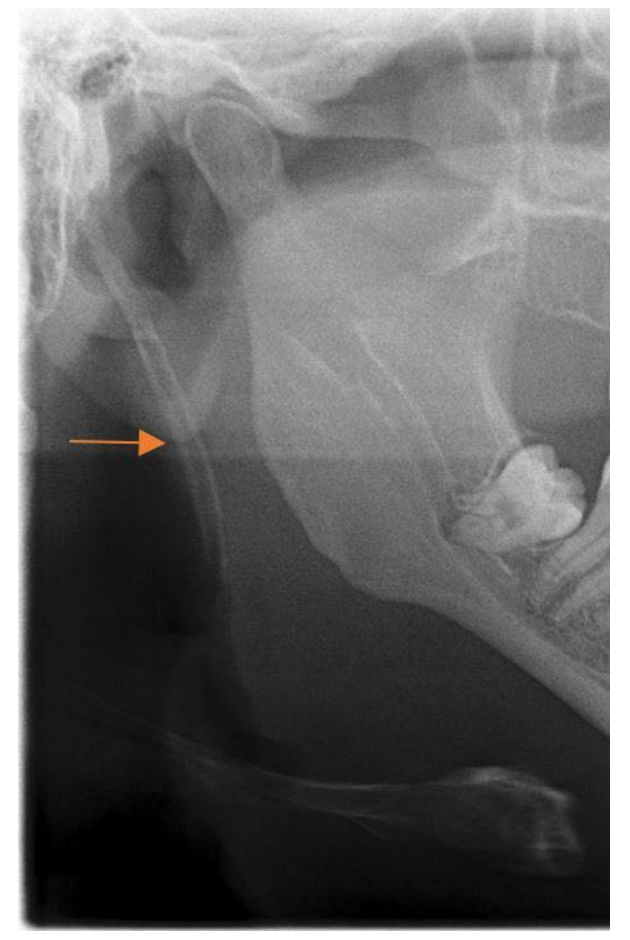

Figure 2. Radiograph show type 1 elongated styloid process.

tal treatment between January 2017 and December 2017. From a diagnostic standpoint, the included digital radiographs had to be adequate, with optimum contrast and density and no distortion or obscuring structure. Poor-quality radiographs with insufficient exposure times or incorrect angulations were removed from this study. All digital radiographs for adult patients that met the study's criteria were examined extensively, and the patients' demographic details, such as gender and age, were registered. Patient information was kept private.

The radiographs were collected from the hospitals' digital archives and imported into the College of Dentistry at Qassim University, Radiology Department's computer system, where they were then displayed. Advanced digital radiograph imaging software (DIGORA ${ }^{\circledR}$ for Windows 2.7; SOREDEX) was used to examine them.

A single professional oral and maxillofacial radiologist reviewed and interpreted all of the radiographs. In a darkened room, all of the radiographs were investigated on the same 21 -inch LCD monitor resolution $(1920 \times 1200$ at $60 \mathrm{~Hz})$; the same environmental conditions prevailed during the examination of all of the radiographs (Figs. 1-4). Each original digital image was magnified using the software's magnification feature, then manipulated by the examiner 


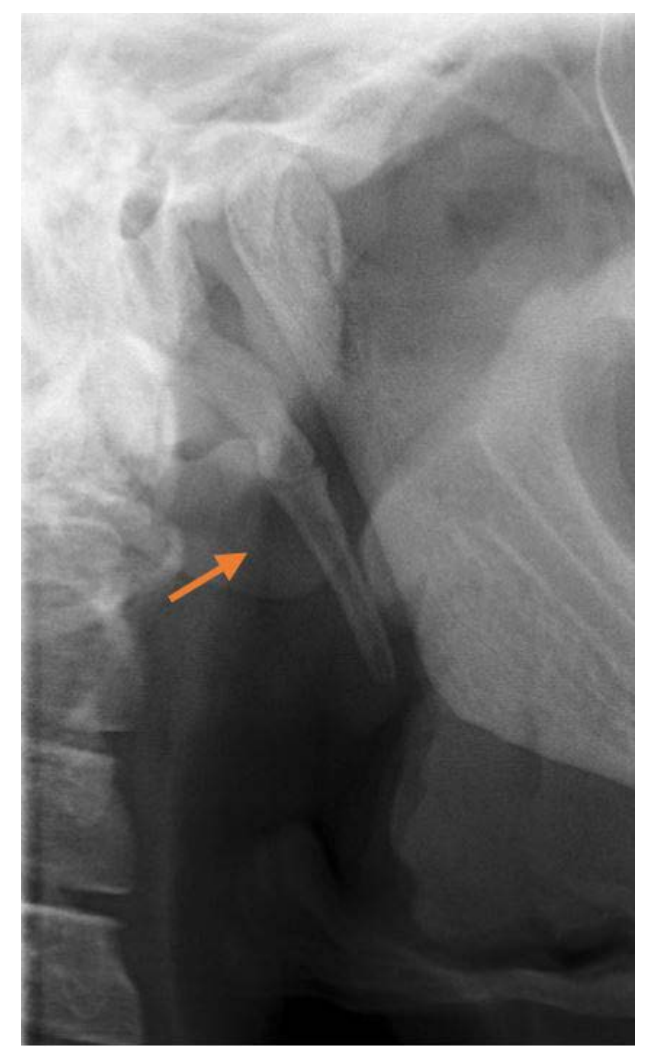

Figure 3. Radiograph show type 2 elongated styloid process.

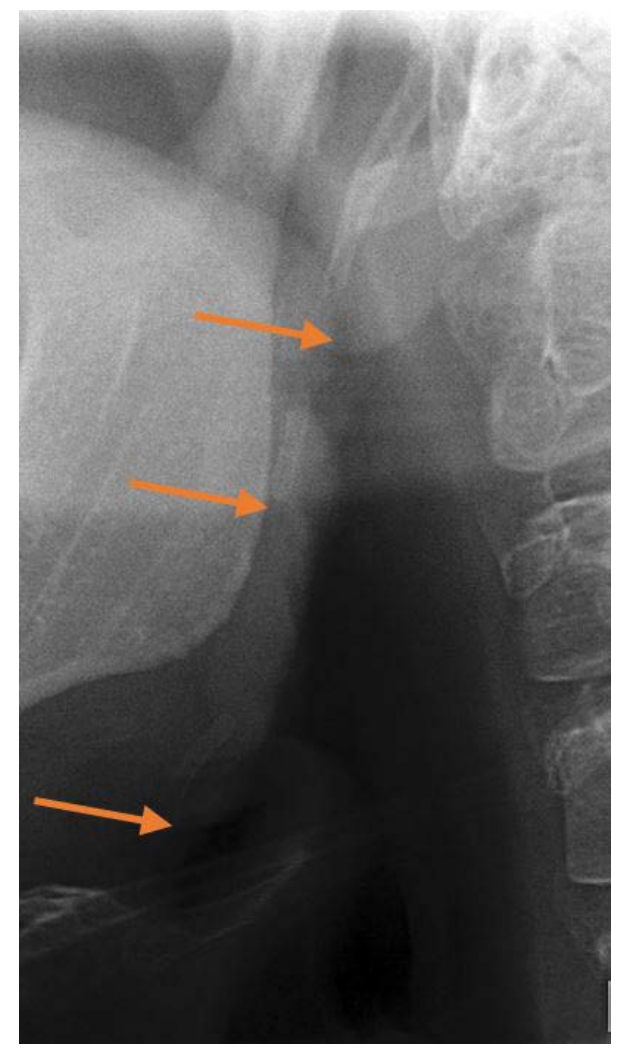

Figure 4. Radiograph show type 3 elongated styloid process.

Table 1. Types of elongated styloid process according to combined Langlais and modified MacDonald-Jankowski classifications [19]

\begin{tabular}{lr}
\hline Type & Characteristics \\
\hline $\begin{array}{l}\text { Type } 0 \text { (normal) } \\
\text { Type } 1 \text { (elongated) }\end{array}$ & $\begin{array}{c}\text { Non elongated styloid process; the tip of the process does not cross the mid portion of mandible body } \\
\text { Uninterrupted styloid process; the tip of the process crosses the mid portion of mandibular body }\end{array}$ \\
$\begin{array}{l}\text { Type } 2 \text { (pseudo-segmented) } \\
\text { The styloid process is apparently joined to the mineralised stylomandibular or stylohyoid ligament by a single } \\
\text { pseudoarticulation, which is usually located superior to a level tangential to the inferior border of the mandible } \\
\text { Type } 3 \text { (segmented) }\end{array}$ & Two or more segments are seen, with interruptions either above or below the level of the inferior border of the mandible \\
\hline
\end{tabular}

to improve the image's contrast and brightness to provide the clearest image in the examined areas.

Sample divided into 1209 and 801 male and female, respectively. They were aged between 20 and 75 years. Data were collected regarding age, gender and SP morphology based on Langlais' classification [19] which classifies the pattern of SP to three types (Table 1).

\section{Statistical analysis}

Data was analysed using the statistical package SPSS 22.0 (SPSS Inc., Chicago, IL) and level of significance was set at $p<0.05$. Inferential statistics was done using $\chi^{2}$ test. The analysis using $\chi^{2}$ test for proportion was done for two variables (age and gender) against the proportion of participants in various patterns of SP elongation.

\section{RESULTS}

Evaluating the SP for 2010 PRs divided into 1209 and 801 male and female, respectively. Sample age ranged between 20 and 75 years with a mean of $34.3 \pm 13.9$ years. The prevalence of type I elongation pattern (uninterrupted integrity of SP) was 382 (19.1\%) cases, of them, 207 and 176 were male and female, respectively (Fig. 2). The mean age of positive type $\mathrm{I}$ is $38 \pm 13.9$ years.

Type II (pseudoarticulation pattern) showed in only $34(1.7 \%)$ cases, of them, 18 and 16 were male and female, respectively, with mean age $35 \pm 13.9$ years (Fig. 3). Type III was present by 92 (4.6\%) cases divided into 60 and 32 male and female, respectively, with mean age $37 \pm 13.9$ years (Fig. 4). Normal SP (non-elongated SP; the tip of the process does not 
Table 2. Descriptive analysis of variables

\begin{tabular}{|c|c|c|c|c|c|c|c|c|c|c|}
\hline \multirow[t]{2}{*}{ Variables } & \multirow[t]{2}{*}{ Category } & \multirow{2}{*}{$\begin{array}{l}\text { Number and } \\
\text { percentage }\end{array}$} & \multicolumn{4}{|c|}{ Styloid process pattern } & \multirow{2}{*}{$\begin{array}{l}\text { Chi-square } \\
\text { value }\end{array}$} & \multirow[t]{2}{*}{$P$ value } & \multirow{2}{*}{$\begin{array}{c}\text { Chi-square } \\
\text { value }\end{array}$} & \multirow[t]{2}{*}{$P$ value } \\
\hline & & & Type I & Type II & Type III & Type 0 & & & & \\
\hline \multirow[t]{2}{*}{ Gender } & Male & $60.1 \%(1209)$ & $17.2 \%(207)$ & $1.6 \%(18)$ & $5 \%(60)$ & $76.2 \%(924)$ & 0.915 & 0.82 & 60.56 & $0.001^{*}$ \\
\hline & Female & $39.8 \%(801)$ & $22 \%(176)$ & $2 \%(16)$ & $4 \%(32)$ & $72 \%(578)$ & & & 57.76 & $0.001^{*}$ \\
\hline \multirow[t]{4}{*}{ Age group } & $18-25$ & $35.4 \%(712)$ & $10.3 \%(73)$ & $0.6 \%(4)$ & $1.3 \%(9)$ & $88 \%(626)$ & 18.80 & $0.026^{*}$ & 83.26 & $0.001 *$ \\
\hline & $26-40$ & $31.0 \%(624)$ & $29.1 \%(181)$ & $2.4 \%(15)$ & $7.4 \%(46)$ & $61 \%(382)$ & & & 42.11 & $0.001^{*}$ \\
\hline & $41-54$ & $23.5 \%(473)$ & $18.7 \%(88)$ & $2 \%(10)$ & $6.2 \%(29)$ & $73 \%(346)$ & & & 54.04 & $0.001^{*}$ \\
\hline & $\geq 55$ & $10.1(204)$ & $20 \%(41)$ & $2.3 \%(5)$ & $4 \%(8)$ & $74 \%(150)$ & & & 59.60 & $0.001^{*}$ \\
\hline
\end{tabular}

${ }^{*} \mathrm{P}<0.05$ is statistically significant

cross the mid portion of mandible body) was showed in 1502 (74.8\%), of them, 924 male and 578 female (Fig. 1). Although statistical analysis reported that there was no statistical significance in gender categories against the proportion of various patterns of SP elongation $\left(p=0.82, X^{2}=0.915\right)$.

Statistical analysis between categories of age against the proportion of various patterns of SP elongation was found to be statistically significant $\left(p=0.026^{*}, X^{2}=18.80\right)$.

The analysis within all age/gender category against the proportion of various patterns of SP elongation reported to be statistically significant $\left(p=0.001^{*}\right)$.

Patients between 26 and 40 years were more affected with type I pattern $\left(p=0.001^{*}\right)$. The least pattern prevalence was type II pattern, it was only seen in $3.6 \%$. Type III was most commonly seen in 26-40 age group with total percentage $7.4 \%$. Normal SP was reported mostly in the youngest age group 18-24 years with 626 cases $\left(p=0.001^{*}\right.$ ) (Table 2 ).

\section{DISCUSSION}

Styloid process term is derived from the Greek word "Stylos" which mean a pillar. It's a cylindrical bone originated from the temporal bone frontal to the stylomastoid foramen [27]. The anatomy of styloid complex includes SP of the temporal bone, stylohyoid ligament and lesser horn of the hyoid bone. SP can be described as slender, pointed, bony projection from the inferior aspect petrous temporal bone. Usually, its length ranges from a few millimetres to an average of $2.5 \mathrm{~cm}$. Its proximal part is unsheathed by the tympanic plate, while muscles and ligaments are attached to its distal part $[22,29]$. SP had been classified by Langlais according to the type of elongation. Langlais classified the SP elongation to three types of complexes. Type I, elongated; type II, pseudoarticulated; and type III, segmented [19].
The diagnosis of elongation of SP were done depending on PRs by many studies including Asutay et al. [1] on East Eagean, Gracco et al. [11] on Italian, Hettiarachchi et al. [12] on Sri Lanken population, Vieira et al. [34] on Brazilian and Sakhdari et al. [30] on Iranian. Other studies had evaluated the SP elongation based on dry skulls, including Vadgaonkar et al. [33] on Indian, Sakaew et al. [32] on Thai, Custodio et al. [5] on Brazilian, Natsis et al. [20] on Greek. In Poland, Iwańczyk et al. [13] published a study of 2 cases were having glomerulonephritis and diagnosed with Eagle syndrome by panoramic radiograph.

Cone beam computed tomography can be used as an advanced diagnostic tool to assess the SP pattern, Buyuk et al. [4], Donmez et al. [7], and Öztunç et al, [21] used it on Turkish population, Kailasam et al [14], and Ramadoss and Sha [31] on Indian population, Khairallah [15], used it on Lebanese population, Andrei et al. [2] used it on Romanian population, Czajka et al. [6] used it in Polish cases.

The normal length of SP ranges between 20 to $30 \mathrm{~mm}$, below $20 \mathrm{~mm}$ is considered as short SP [16], while many studies suggest that SP should be considered elongated when it is longer than $30 \mathrm{~mm}$ $[3,17,18,30,32]$. Although, there is limited number of studies considering the SP elongated when it exceeds $45 \mathrm{~mm}$ [35].

This study found the prevalence of elongated SP in $36.8 \%$ of total samples, all $36.8 \%$ have SPs lengthening more than $30 \mathrm{~mm}$ and crossing the mid portion of mandibular body. While $56.6 \%$ of the samples had normal length SPs ranging $20-30 \mathrm{~mm}$ and the tip of the process did not cross the mid portion of mandible body.

In the present study, men were slightly more affected with different pattern of SPs, although no significant difference were proven considering male to female sample number $\left(p=0.82, X^{2}=0.915\right)$. 
Investigation showed 293 out of 879 cases with unilateral elongated SPs while bilateral was reported in 586 cases. This is consisted with other studies including Sakhdari et al. [30] and Vieira et al. [34].

Further studies using computed tomography or cone-beam computed tomography for a three-dimensional evaluation of the SP are required to investigate in specific the prevalence of different pattern SP in Qassim population, Saudi Arabia.

\section{CONCLUSIONS}

Styloid process has many patterns and variations that could be detected on digital PRs taken daily in most of dental clinics. Elongated SP may often be asymptomatic, they can only be diagnosed coincidentally by routine PRs. Dentists should be trained to detect patients with such variation so that signs associated with Eagle syndrome are not misinterpreted.

\section{Conflict of interest: None declared}

\section{REFERENCES}

1. Asutay F, Erdem N, Atalay Y, et al. Prevalence of elongated styloid process and eagle syndrome in east eagean population. Bezmialem Science. 2019; 7(1): 28-32, doi: 10.14235/bas.galenos.2018.991.

2. Andrei F, Motoc AG, Didilescu AC, et al. A 3D cone beam computed tomography study of the styloid process of the temporal bone. Folia Morphol. 2013; 72(1): 29-35, doi: 10.5603/fm.2013.0005, indexed in Pubmed: 23749708.

3. Bagga MB, Kumar CA, Yeluri G. Clinicoradiologic evaluation of styloid process calcification. Imaging Sci Dent. 2012; 42(3): 155-161, doi: 10.5624/isd.2012.42.3.155, indexed in Pubmed: 23071965.

4. Buyuk C, Gunduz K, Avsever H. Morphological assessment of the stylohyoid complex variations with cone beam computed tomography in a Turkish population. Folia Morphol. 2018; 77(1): 79-89, doi: 10.5603/FM.a2017.0061, indexed in Pubmed: 28653301.

5. Custodio AL, Silva MR, Abreu MH, et al. Styloid process of the temporal bone: morphometric analysis and clinical implications. Biomed Res Int. 2016; 2016: 8792725, doi: 10.1155/2016/8792725, indexed in Pubmed: 27703982.

6. Czajka M, Szuta M, Zapała J, et al. Assessment of surgical treatment of Eagle's syndrome. Otolaryngol Pol. 2019; 73(3): 1-5, doi: 10.5604/01.3001.0013.1533.

7. Donmez M, Okumus O, Pekiner FN. Cone beam computed tomographic evaluation of styloid process: A retrospective study of 1000 patients. Eur J Dent. 2017; 11(2): 210-215, doi: 10.4103/ejd.ejd_56_17, indexed in Pubmed: 28729795.

8. Eagle WW. Elongated styloid process: Report of two cases. Arch Otolaryngol Head Neck Surg. 1937; 25(5): 584-587, doi: 10.1001/archotol.1937.00650010656008.

9. Ferreira PC, Mendanha M, Frada T, et al. Eagle syndrome. J Craniofac Surg. 2014; 25(1): e84-e86, doi:
10.1097/SCS.0000000000000392, indexed in Pubmed: 24406612.

10. Gokce C, Sisman Y, Ertas ET, et al. Prevalence of styloid process elongation on panoramic radiography in the Turkey population from cappadocia region. Eur J Dent. 2008; 2(1): 18-22, indexed in Pubmed: 19212504.

11. Gracco A, De Stefani A, Bruno G, et al. Elongated styloid process evaluation on digital panoramic radiograph in a North Italian population. J Clin Exp Dent. 2017; 9(3): e400-e404, doi: 10.4317/jced.53450, indexed in Pubmed: 28298982.

12. Hettiarachchi PV, Jayasinghe RM, Fonseka MC, et al. Evaluation of the styloid process in a Sri Lankan population using digital panoramic radiographs. J Oral Biol Craniofac Res. 2019; 9(1): 73-76, doi: 10.1016/j.jobcr.2018.10.001, indexed in Pubmed: 30302305.

13. Iwańczyk B, Nowak J, Szerszeń M, et al. Elongation of the styloid process - Eagle syndrome - case reports of patients on dialysis. Dental Medical Problems. 2015; 52: 366-370.

14. Kailasam S, Massillamani F, Potluri V, et al. Morphometric evaluation of styloid process using cone beam computed tomography: a retrospective study of chennai population. J Adv Med Med Res. 2018; 25(8): 1-12, doi: 10.9734/ jammr/2018/39071.

15. Khairallah A. CBCT findings of complete calcification of the stylohyoide ligament: case reports. J Dent Health Oral Disord Ther. 2015; 2(2), doi: 10.15406/jdhodt.2015.02.00040.

16. Koshy JM, Narayan M, Narayanan S, et al. Elongated styloid process: A study. J Pharm Bioallied Sci. 2015; 7(Suppl 1): S131-S133, doi: 10.4103/0975-7406.155861, indexed in Pubmed: 26015690.

17. Kaufman SM, Elzay RP, Irish EF. Styloid process variation. Radiologic and clinical study. Arch Otolaryngol. 1970; 91(5): 460-463, doi: 10.1001/archotol.1970.00770040654013, indexed in Pubmed: 5442737.

18. Keur JJ, Campbell JP, McCarthy JF, et al. The clinical significance of the elongated styloid process. Oral Surg Oral Med Oral Pathol. 1986; 61(4): 399-404, doi: 10.1016/00304220(86)90426-3, indexed in Pubmed: 3458151.

19. Langlais R, Miles D, Dis MV. Elongated and mineralized stylohyoid ligament complex: A proposed classification and report of a case of Eagle's syndrome. Oral Surgery, Oral Medicine, Oral Pathology. 1986; 61(5): 527-532, doi: 10.1016/0030-4220(86)90400-7.

20. Natsis K, Repousi E, Noussios G, et al. The styloid process in a Greek population: an anatomical study with clinical implications. Anat Sci Int. 2015; 90(2): 67-74, doi: 10.1007/ s12565-014-0232-3, indexed in Pubmed: 24664363.

21. Oztunç H, Evlice B, Tatli U, et al. Cone-beam computed tomographic evaluation of styloid process: a retrospective study of 208 patients with orofacial pain. Head Face Med. 2014; 10: 5, doi: 10.1186/1746-160X-10-5, indexed in Pubmed: 24528515.

22. Patil S, Ghosh S, Vasudeva N. Morphometric study of the styloid process of temporal bone. J Clin Diagn Res. 2014; 8(9): AC04-AC06, doi: 10.7860/JCDR/2014/9419.4867, indexed in Pubmed: 25386413.

23. Rodríguez-Vázquez JF, Mérida-Velasco JR, Verdugo-López S, et al. Morphogenesis of the second pharyngeal arch cartilage (Reichert's cartilage) in human embryos. 
J Anat. 2006; 208(2): 179-189, doi: 10.1111/j.14697580.2006.00524.x, indexed in Pubmed: 16441562.

24. Radak D, Tanaskovic S, Kecmanovic V, et al. Bilateral Eagle syndrome with associated internal carotid artery kinking and significant stenosis. Ann Vasc Surg. 2016; 34: 271. e15-271.e18, doi: 10.1016/j.avsg.2016.01.015, indexed in Pubmed: 27174357.

25. Shah N, Bansal N, Logani A. Recent advances in imaging technologies in dentistry. World J Radiol. 2014; 6(10): 794-807, doi: 10.4329/wjr.v6.i10.794, indexed in Pubmed: 25349663.

26. Sridevi K, Mahesh N, Krishnaveni B, et al. Evaluation of styloid process and its anatomical variations: a digital panoramic study with systematic review. J Int Soc Prev Community Dent. 2019; 9(3): 256-262, doi: 10.4103/ jispcd.JISPCD_8_19, indexed in Pubmed: 31198698.

27. Sudhakara RR, Sai Kiran Ch, Sai Madhavi N. Journal of the Spanish Society of Oral Surgery. Prevalence of elongation and calcification patterns of elongated styloid process in south India. 2013; 5(1): 30-35.

28. Saccomanno S, Greco F, DE Corso E, et al. Eagle's Syndrome, from clinical presentation to diagnosis and surgical treatment: a case report. Acta Otorhinolaryngol Ital. 2018; 38(2): 166-169, doi: 10.14639/0392-100X-1479, indexed in Pubmed: 29967562.

29. Standring S. Gray's Anatomy: The Anatomical Basis of Clinical Practice. 40th ed. Churchill Livingstone, New York 2008.
30. Sakhdari S, Saberi S, Shamshiri AR. Prevalence and pattern of styloid process elongation and calcification on digital panoramic radiographs in an iranian population. J Islam Dent Assoc Iran. 2018; 30(2): 44-51, doi: 10.30699/ jisdreir.30.2.44.

31. Ramadoss T, Sha K. Assessment of the styloid process by cone beam computed tomography. Int J Radiol Radiat Ther. 2017; 2(5): 123-127, doi: 10.15406/ijrrt.2017.02.00038.

32. Sakaew W, Arnanteerakul T, Somintara S, et al. Sexual dimorphism using the interstyloid distances and clinical implication for elongated styloid process in northeastern thailand. Int J Morphol. 2016; 34(4): 1223-1227, doi: 10.4067/s0717-95022016000400008.

33. Vadgaonkar R, Murlimanju BV, Prabhu LV, et al. Morphological study of styloid process of the temporal bone and its clinical implications. Anat Cell Biol. 2015; 48(3): 195-200, doi: 10.5115/acb.2015.48.3.195, indexed in Pubmed: 26417479.

34. Vieira EM, Guedes OA, Morais SD, et al. Prevalence of Elongated Styloid Process in a Central Brazilian Population. J Clin Diagn Res. 2015; 9(9): ZC90-ZC92, doi: 10.7860/ JCDR/2015/14599.6567, indexed in Pubmed: 26501021.

35. Jung $T$, Tschernitschek $\mathrm{H}$, Hippen $\mathrm{H}$, et al. Elongated styloid process: when is it really elongated? Dentomaxillofac Radiol. 2004; 33(2): 119-124, doi: 10.1259/dmfr/13491574, indexed in Pubmed: 15314005. 